\title{
Aminoterminal Propeptides of Type III Procollagen in Human Cerebrospinal Fluid
}

\author{
By A. M. Gressner
}

Abteilung für Klinische Chemie and Pathobiochemie der Medizinischen Facultät der RWTH Aachen

(Received October 18/December 5, 1983)

Summary: The concentrations of aminoterminal propeptides of procollagen type III were determined by radioimmunoassay in the cerebrospinal fluids of 64 patients with various neurological disorders, including 4 infant patients ( $<1$ year). In cerebrospinal fluids of adult patients with normal composition (protein, glucose, cell count), adult patients with pathologic composition, and infant patients the peptide levels (mean value \pm S.D.) were $4.07 \pm 1.26 \mu \mathrm{g} / \mathrm{l}, 8.15 \pm 6.78 \mu \mathrm{g} / \mathrm{l}$, and $56.9 \pm 31.0 \mu \mathrm{g} / \mathrm{l}$, respectively. The concentrations ranged from 1.96 to $265 \mu \mathrm{g} / \mathrm{l}$ and were independent of the respective serum propeptide levels. No statistic correlation with other parameters was found. Gel chromatography revealed a high degree of molecular weight heterogeneity, a substantial portion of immunoreactive material was eluted even with the void volume of Sephacryl S 300. Different slopes of radioimmunoinhibition curves indicate heterogenous antigenicity among the propeptides from various patients. Interaction of the propeptides with fibronectin and/or heparin is probably not responsible for the heterogeneity. The diagnostic potential of cerebrospinal fluid propeptide levels for local connective tissue (collagen) turnover remains to be elucidated.

\section{Aminoterminale Propeptide von Typ III Prokollagen im Liquor cerebrospinalis des Menschen}

Zusammenfassung: Im Liquor cerebrospinalis von 64 Patienten mit verschiedenen neurologischen Erkrankungen einschließlich 4 Kleinkindern $(<1 \mathrm{Jahr}$ ) wurden die Konzentrationen der aminoterminalen Propeptide von Prokollagen Typ III mit einem Radioimmunoassay bestimmt. In Liquores von erwachsenen Patienten mit normaler Zusammensetzung (Protein, Glucose, Zellzahl), erwachsenen Patienten mit pathologischer Zusammensetzung und Kleinkindern wurden Peptidkonzentrationen (Mittelwert \pm S.D.) von 4,07 \pm $1,26 \mu \mathrm{g} / 1,8,15 \pm 6,78 \mu \mathrm{g} / \mathrm{l}$ bzw. 56,9 $\pm 31,0 \mu \mathrm{g} / \mathrm{l}$ gemessen. Die Konzentrationen erstreckten sich von 1,96 bis $265 \mu \mathrm{g} / 1$ und waren unabhängig von der jeweiligen Propeptid-Konzentration im Serum. Eine statistische Korrelation mit anderèn Kenngrößen bestèht nicht. Gelchromatographie weist einen hohen Grad an Heterogenität bezüglich des Molekulargewichtes nach, ein beträchtlicher Anteil des immunreaktiven Materials wird mit dem Ausschlußvolumen von Sephacryl S 300 eluiert. Unterschiede in den Steigungen der RadioimmunoInhibitionskurven weisen auf heterogene Antigenität der Propeptide verschiedener Patienten hin. Interaktionen der Propeptide mit Fibronectin und/oder Heparin sind wahrscheinlich nicht verantwortlich für diese Heterogenität. Die diagnostische Bedeutung der Propeptidkonzentrationen im Liquor cerebrospinalis für den lokalen Bindegewebsstoffwechsel bedarf weiterer Klärung.

\section{Introduction}

Collagen is a major secretory protein of a large number of eukaryotic cells. Like other proteins $(1-3)$ synthesized on membrane bound polysomes and destined for export into the extracellular space, collagen mRNA is translated initially into a preprocollagen having $\mathrm{NH}_{2}$-terminal hydrophobic extensions ("signal sequences") (4) which are required for the unidirectional transfer of the nascent polypeptide into the lumen of the endoplasmic reticulum (5). 
These sequences are removed intracellularly by endoproteolytic activities to yield procollagen. After secretion the procollagen molecule is further modified by procollagen peptidases cleaving both from the amino-and carboxy-terminal end propeptides (6, 7) which can be determined by competitive radioimmunoassays in various human body fluids such as serum, urine, amniotic and ascitic fluid $(8-11)$. The aminoterminal propeptide of type III procollagen in serum has been suggested as a sensitive parameter for diagnosis and follow up of fibroproliferative liver disorders $(12,13)$. In human cerebrospinal fluid the presence of the carboxyterminal propeptide of type I procollagen was claimed (14) but details are missing. In addition, there are no reports on the aminoterminal propeptide of type III procollagen in cerebrospinal fluid available. Because the cleavage product of collagen processing might be a candidate parameter of local connective tissue (collagen) formation activity, we measured the peptide in cerebrospinal fluid of adult and infant patients with various neurological disorders and determined the molecular weight composition and some of the antigenic properties of the procollagen propeptides.

\section{Materials and Methods}

Specimen collection

Cerebrospinal fluid was obtained by lumbar puncture from 60 adult patient with various neurological diseases including mainly encephalitis, meningitis, multiple sclerosis, primary and secondary tumours, insult, circulatory disturbances and polyneuropathy. Four specimens from infant patients ( $>1$ year of age) were also studied. In 5 cases, it was possible to sample cerebrospinal fluid on more than one occasion (two to three times). The fluid was separated from cells by centrifugation $(10 \mathrm{~min}, 2000 \mathrm{~g}$ ) within $5 \mathrm{~h}$ after lumbar puncture and stored until use at $-20^{\circ} \mathrm{C}$. The sample was regarded as pathologic if the concentration of total protein exceeded $0.45 \mathrm{~g} / \mathrm{l}$ and/or the total cell count was above $4 \mu \mathrm{l}^{-1}$. Total protein and glucose in cerebrospinal fluid were measured with a biuret (15) and hexokinase method (16), respectively. Cells were counted manually by routine procedures. In some cases the serum of the patients was analysed simultaneously. One patient with histological proven chronic active Non-A-Non-B-hepatitis served as a control (fig. 3).

Determination of the aminoterminal propeptide of type III procollagen

Various dilutions of cerebrospinal fluid in phosphate-buffered saline (normally $1: 2,1: 5,1: 10$ ) were analysed for the propeptide using a radioimmunoassay for aminoterminal procollagen III peptide (Behring-Werke/Hoechst AG, Frankfurt) which has been described in detail elsewhere (11). The intra-assay coefficient of variation (CV) was $5.5 \%(\overline{\mathrm{x}}=9.8 \mu \mathrm{g} / \mathrm{l}, \mathrm{n}=8)$, the inter-assay CV was $8 \%(\bar{x} 3.3 \mu \mathrm{g} / \mathrm{l}, \mathrm{n}=10)$.

Determination of the molecular weight composition of the antigenic material

A column $(1 \times 120 \mathrm{~cm})$ of Sephadex G 100 (Pharmacia Fine Chemicals, Uppsala) equilibrated with $0.1 \mathrm{~mol} / 1$ Tris- $\mathrm{HCl}$, $\mathrm{pH} 7.4$ $\left(20^{\circ} \mathrm{C}\right)$ was calibrated with standard proteins of the low molecular weight gel filtration calibration kit (Pharmacia) indicated in figure 3. $V_{0}$ was determined with thyroglobulin $\left(M_{\mathrm{r}} 669000\right), \mathrm{V}_{\mathrm{t}}$ with $\mathrm{NAD}^{+}\left(M_{\mathrm{r}}=681\right)$. Cerebrospinal fluid ( $1 \mathrm{ml}$, containing $4.6 \mathrm{ng}$ propeptide) diluted with $0.5 \mathrm{ml}$ Tris- $\mathrm{HCl}$ buffer was applied and the effluent fractionated into $1 \mathrm{ml}$ portions in which the relative peptide concentrations indicated by $\%$ inhibition of the binding of ${ }_{125}$ I-labeled bovine propeptide to the antibody were recorded.

The $K_{a v}=\frac{V_{c}-V_{o}}{V_{t}-V_{0}}$ was determined and the molecular weights of the main fractions (I-IV) were calculated by use of the calibration curve.

Interaction of procollagen peptides with fibronectin and heparin

To study some possible interactions of procollagen peptides with fibronectin and heparin various dilutions of cerebrospinal fluids in phosphate-buffered saline were incubated in a total volume of $1.2 \mathrm{ml}$ for $1 \mathrm{~h}$ at $4{ }^{\circ} \mathrm{C}$ and $37^{\circ} \mathrm{C}$, with $10 \mu \mathrm{g}$ human plasma fibronectin (lot. F-2006, Sigma Chemical Comp., München) and/or $50 \mu \mathrm{g}$ heparin (from porcine intestinal mucosa, Sigma Chemical Comp.); control samples were incubated in the absence of both compounds. Thereafter the elution profiles of procollagen peptides from a Sephacryl S 300 column $(1 \times 115 \mathrm{~cm})$, calibrated with molecular weight standard proteins as above, were recorded. In addition, radioimmuno-inhibition curves of the various procollagen peptide incubations were tested. Details are described in the legends to figures 5 and 6.

\section{Statistical analysis}

The significance of differences was tested with the Mann-Whitney test (17).

\section{Results}

Procollagen type III propeptide concentrations in cerebrospinal fluid

Procollagen peptide was present in the cerebrospinal fluid of each patient studied (fig. 1). The lowest concentration observed was $1.96 \mu \mathrm{g} / \mathrm{l}$, the highest 265 $\mu \mathrm{g} / \mathrm{l}$. Adult patients having both normal protein concentration and cell count were found to have a peptide concentration (mean value \pm S.D.) of $4.07 \pm$ $1.26 \mu \mathrm{g} / \mathrm{l}$, whereas infant patients $(<1$ year of age) exhibit a significantly higher $(p=0.001)$ level of procollagen peptide in cerebrospinal fluid (56.9 \pm $31.0 \mu \mathrm{g} / \mathrm{l})$, despite a normal concentration of protein and normal cell count (fig. 1). In adult patients with pathologic composition (protein and/or cell count above the reference range) of the cerebrospinal fluid, the procollagen peptide concentrations exceeded in nearly $50 \%(7 / 15)$ the +2 SD limit of adult patients with normal fluid composition (fig. 1). The concentration (mean \pm S.D.) was $8.15 \pm 6.78$ $\mu \mathrm{g} / \mathrm{l}$, the two extreme concentrations observed (150 and $265 \mu \mathrm{g} / \mathrm{l}$ ) were not included in the calculation of the mean concentration. Thus, the level of propeptide in this group of patients is significantly higher than that in adult patients with normal cerebrospinal fluid $(p=0.0028)$ and significantly lower $(p=$ 0.0356 ) than that in infant patients. 


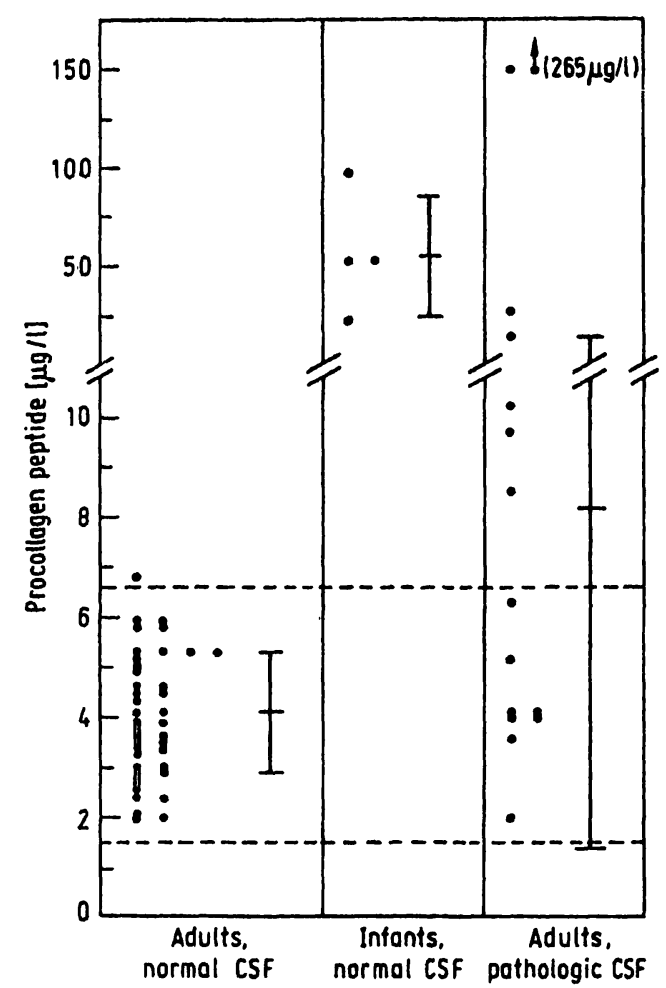

Fig. 1. Frequency distribution of $\mathrm{NH}_{2}$-terminal procollagen peptide type III concentrations in cerebrospinal fluids (CSF) of adult patients having normal fluid composition (i.e. total protein, glucosc and cell count within the reference range) $(n=45)$, infants ( $<1$ year) with normal cerebrospinal fluid $(n=4)$, and adult patients having at least one of the parameters (protein, glucose, cell count) in the pathologic range $(n=15)$. The mean concentrations \pm S.D. of each group are given. In the latter group the 2 patients with peptide concentrations of $150 \mu \mathrm{g} / \mathrm{l}$ and more $(265 \mu \mathrm{g} / \mathrm{l})$ were excluded from the calculation of mean value \pm S.D. The dotted lines indicate the \pm 2 S.D. limits of peptide levels in adults with normal CSF composition.

A correlation of the peptide concentration with a specific neurological disorder is not yet possible. The patient having a peptide level of $265 \mu \mathrm{g} / \mathrm{l}$ suffered from haemangioblastoma, while the patient with 150 $\mu \mathrm{g} / \mathrm{l}$ peptide was treated because of an aneurysm of art. basilaris. Other patients with elevated procollagen peptide concentrations suffered from tumours, myelitis, or influenza encephalitis. Multiple sclerosis $(n=6)$ was not associated with increased peptide levels.

No statistical correlation was found between the aminoterminal propeptide concentrations and the concentration of total protein $(r=0.357)$, glucose, or cell count.

The concentration of procollagen peptide in cerebrospinal fluids can change quite rapidly (fig. 2). $\mathrm{Pa}$ tients studied repeatedly at intervals of 2 to 4 weeks exhibited different peptide levels which are associated in some cases with similar changes of the total protein concentration. However, there is by no means a strict correlation between the quantitative changes of both parameters (fig. 2).

In the patients studied, cerebrospinal fluid propeptide concentrations were found to be independent of the respective peptide levels in serum (tab. 1). The two patients with respectively low and highly elevated cerebrospinal fluid concentrations, showed similar concentrations of the antigen in serum. Despite identical peptide concentrations in blood, the concentration of the respective material in cerebrospinal fluid might differ more than 14 fold (tab. 1).

Tab. 1. Serum: cerebrospinal fluid ratios of procollagen peptide in six patients having normal and highly elevated concentrations of procollagen peptide in cerebrospinal fluid.

\begin{tabular}{lrc}
\hline \multicolumn{2}{c}{ Procollagen peptide $(\mu \mathrm{g} / \mathrm{l})$} & Serum \\
Cerebrospinal fluid & Serum & Cercbrospinal fluid \\
\hline 2.9 & 13.8 & 4.76 \\
3.9 & 10.1 & 2.56 \\
5.1 & 7.9 & 1.56 \\
26.2 & 7.9 & 0.30 \\
34.0 & 12.9 & 0.38 \\
41.4 & 13.6 & 0.32 \\
\hline
\end{tabular}
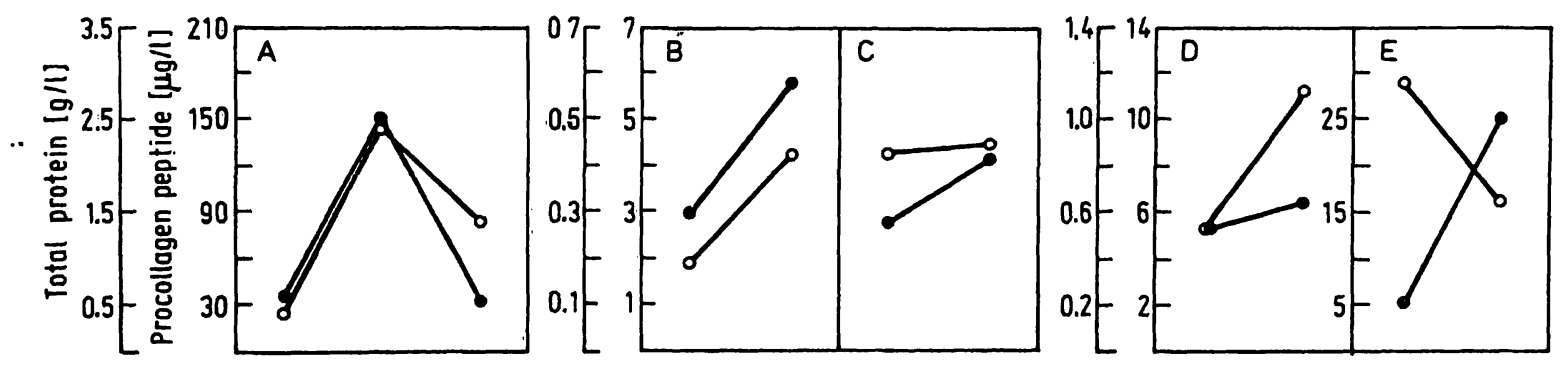

Fig. 2. Follow up of the concentrations of procollagen peptide $(--0)$ and total protcin $(0-0)$ in cercbrospinal fluids of five patients. The interval between the determinations was about 2-4 weeks. Clinical diagnosis:
A) art. basilaris aneurysm;
B) multiple sclerosis;
C) diagnosis uncertain, patient died;
D) prolapse of an intervertebral disk;
E) influenza encephalitis 
Heterogeneity of procollagen type III peptides in cerebrospinal fluid.

Cerebrospinal fluid of a patient with polyneuropathy $(4.6 \mu \mathrm{g} / \mathrm{l})$ was subjected to gel filtration on Sephadex G 100 and the distribution of immunoreactive material was recorded in the effluent volume (fig. 3). Four main fractions were obtained, and the bulk fraction was eluted with the void volume of the column. Qualitatively similar elution profiles of procollagen peptides were obtained with the serum of a patient with chronic active hepatitis and with the procollagen peptide standard of bovine origin supplied by the manufacturer (fig. 3 ).

The molecular weights corresponding to the peak peptide fractions in figure 3 are listed in table 2. They indicate the high molecular weight nature of the bulk fraction (I) and similar molecular weight distributions of propeptides in cerebrospinal fluid, serum and standard. Thus, the molecular weight of antigenic material in cerebrospinal fluid comprises a wide range which is far above that reported for the aminoterminal propeptide (11).

Differences in the radioimmunoinhibition curves reveal further heterogeneity of the antigenic material in cerebrospinal fluids. As illustrated in figure 4, the inhibition plots for cerebrospinal fluid and serum showed different slopes, which are not dependent on the concentration of the propeptide in the fluids.
Tab. 2. Molecular weights (daltons) of the peak fractions of procollagen type III peptides in cerebrospinal fluid of a patient with polyneuropathy. They were calculated from the $\mathrm{K}_{\mathrm{av}}$ determined on Sephadex $\mathrm{G} 100$ (fig. 3). The molecular weights of the peptides are compared with those in the serum of a patient with Non-A-Non-B-chronic active hepatitis, and with the standard procollagen III peptide supplied by the manufacturer.

\begin{tabular}{llrr}
\hline Peak fraction & $\begin{array}{l}\text { Cerebrospinal } \\
\text { fluid }\end{array}$ & Serum & $\begin{array}{l}\text { Standard } \\
\text { procollagen } \\
\text { III peptide }\end{array}$ \\
\hline I & $>100000$ & $>100000$ & $>100000$ \\
II & 76000 & 68000 & 68000 \\
III & 45000 & 41000 & 56000 \\
IV & 35000 & 27000 & 37000 \\
\hline
\end{tabular}

Fibronectin binds efficiently to collagen and collagen-derived fragments $(18-20)$, in particular of type III origin. In addition, heparin was reported to enhance this binding (21). The possibility that heterogeneity may be due to interaction of propeptides with fibronectin and/or heparin was tested by gel chromatography, and by radioimmunoinhibition curves. Incubation at $37^{\circ} \mathrm{C}$ or $4^{\circ} \mathrm{C}$ of cerebrospinal fluids with various amounts of fibronectin, normally present in cerebrospinal fluid only in very low concentrations $(22,23)$, did not alter significantly the elution profiles of propeptides from Sephacryl S 300

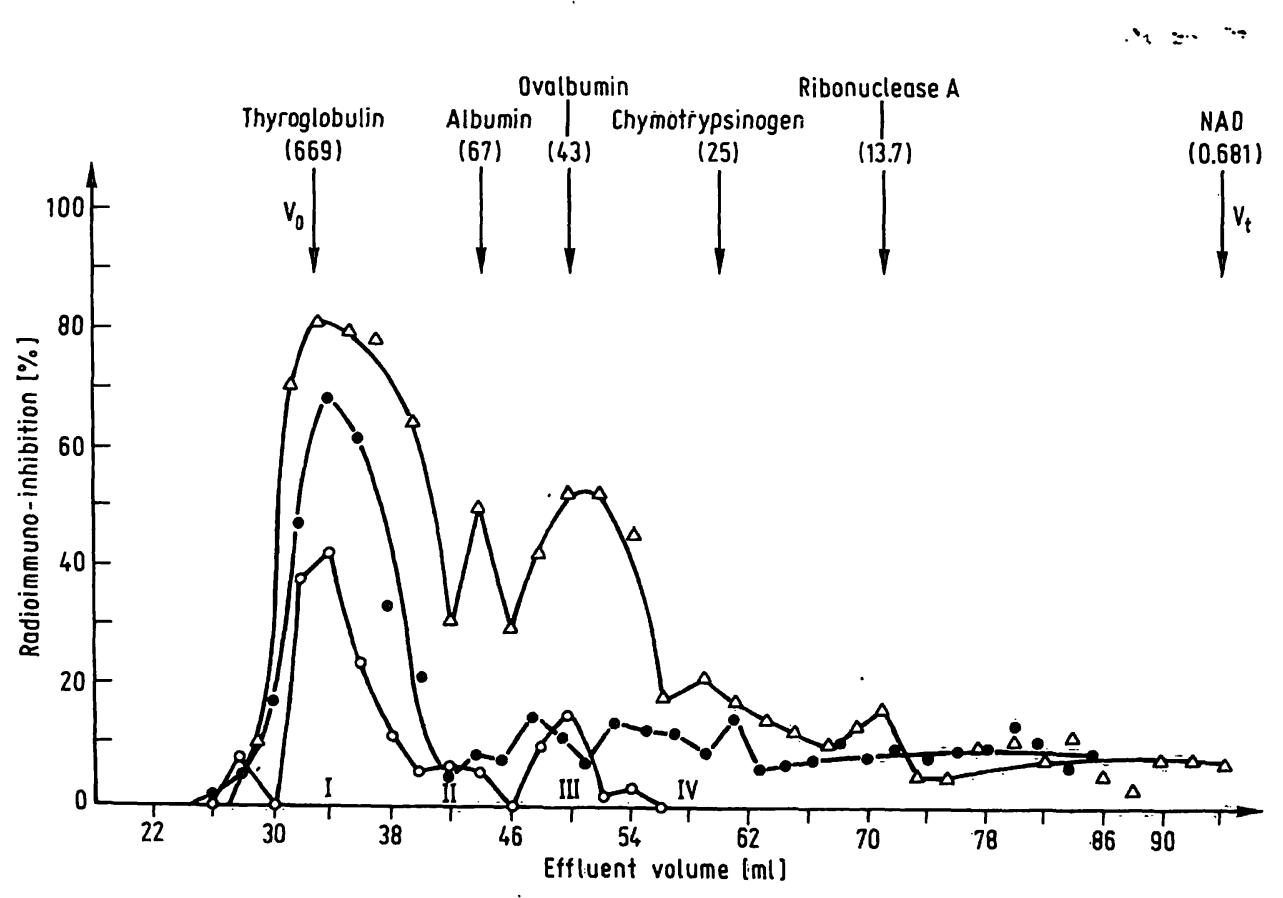

Fig. 3. Elution profiles from a Sephadex G 100 column of immunoreactive procollagen peptides from cerebrospinal fluid of a patient with polyneuropathy $(O-O$, concentration $4.6 \mu \mathrm{g} / \mathrm{l})$, serum of a patient with chronic active hepatitis $(\Delta-\Delta$, concentration 44.2 $\mu \mathrm{g} / \mathrm{l})$, and of the procollagen peptide standard $(0-0$, concentration $5.3 \mu \mathrm{g} / \mathrm{l})$ supplied with the assay kit. The column was equilibrated with $0.1 \mathrm{~mol} / 1$ Tris- $\mathrm{HCl}, \mathrm{pH} 7.4$, calibrated with various molecular weight standard proteins of which the $\mathrm{k}$ daltons are given in parentheses. The four peak fractions $(I-I V)$ are indicated; their molecular weights were estimated from $K_{\mathrm{av}}(\operatorname{tab} .2)$. 


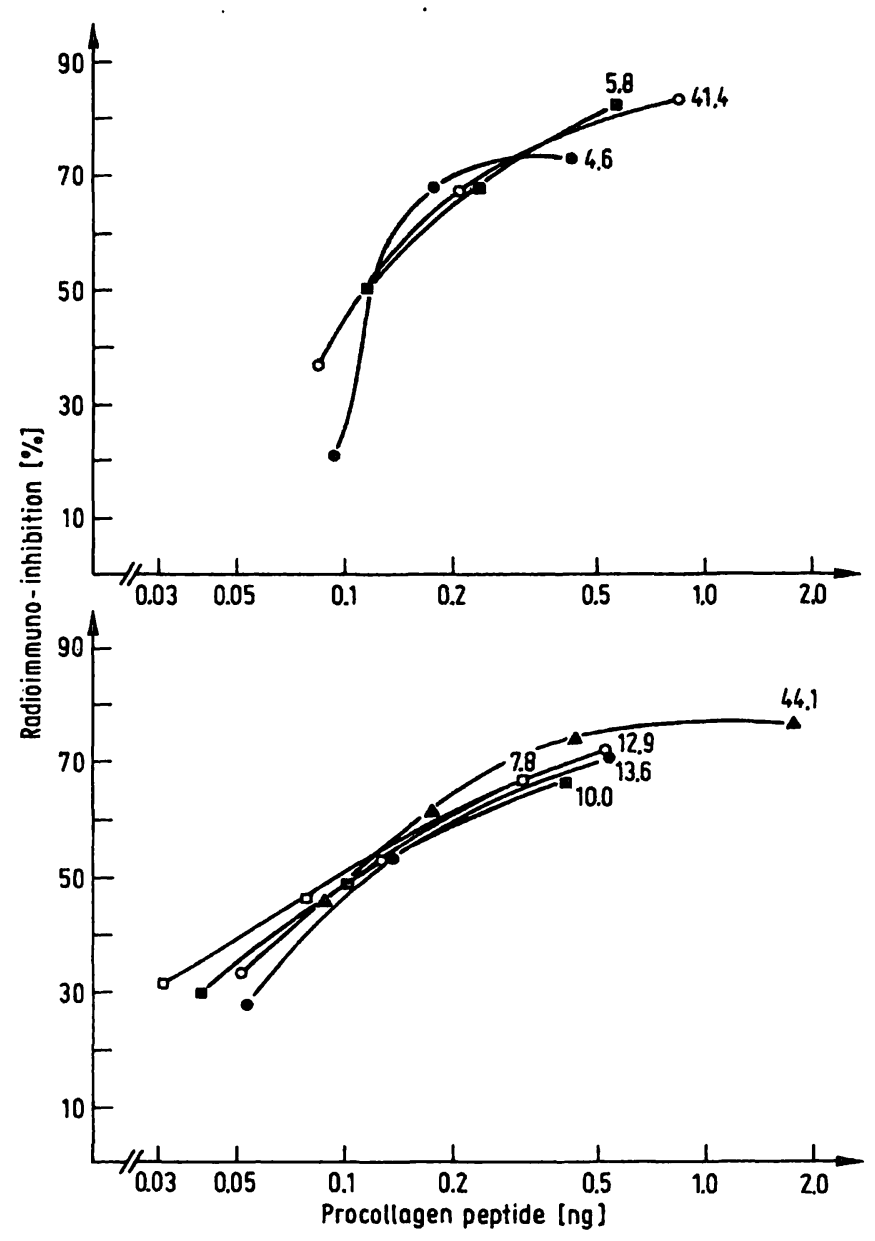

Fig. 4. Radioimmunoinhibition curves of 3 cerebrospinal fluid samples (a) and 5 serum samples (b) with various concentrations $(\mu \mathrm{g} / \mathrm{l})$ indicated by the numbers. The samples were diluted to give the final amounts (ng) of procollagen peptide in the assay of which the potency to inhibit the binding of bovine $\left[{ }^{125}\right.$ I $]$ procollagen III peptide to the antibody was tested (\% inhibition). (fig. 5). At the position where pure fibronectin elutes from the column no immunreactive procollagen peptide was detected.

The radioimmunoinhibition curves of cerebrospinal fluid propeptide were not influenced by incubation of the sample with fibronectin and/or heparin (fig. 6).

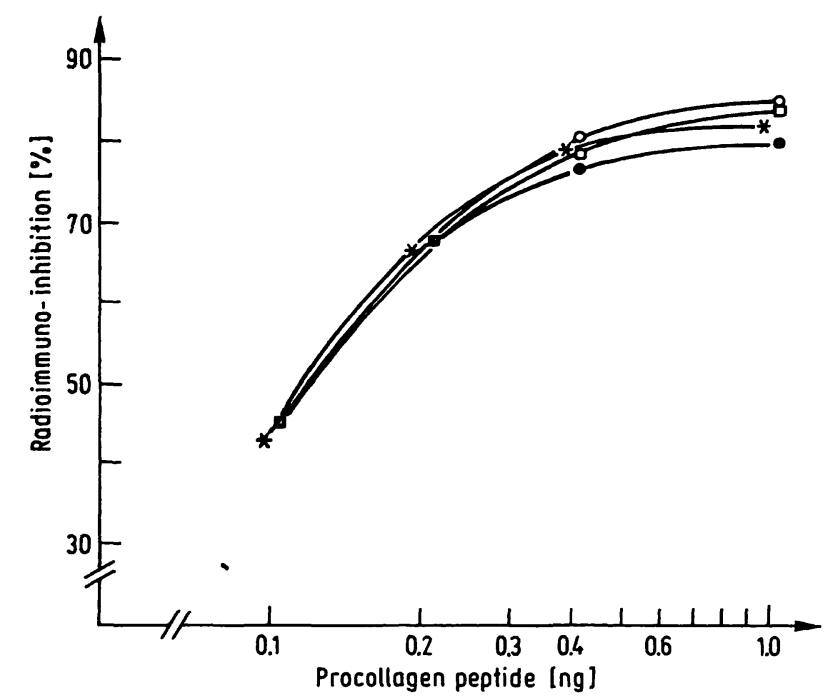

Fig. 6. Radioimmunoinhibition curves of a cerebrospinal fluid sample in the presence of heparin $(\mathrm{O}-\mathrm{O})$, fibronectin $(\square-\square)$, heparin and fibronectin $(\star-\star)$, and in the absence of both heparin and fibronectin $(0-0)$.

$1.0 \mathrm{ml}$ of cerebrospinal fluid containing $10.5 \mathrm{ng}$ procollagen peptide was incubated for $1 \mathrm{~h}$ at $37^{\circ} \mathrm{C}$ with $50 \mu \mathrm{g}$ heparin and/or $10 \mu \mathrm{g}$ fibronectin, controls were incubated with phosphate-buffered saline alone. The inhibition curves were obtained as described in figure 4 . Similar results were obtained by incubations at $4^{\circ} \mathrm{C}$.

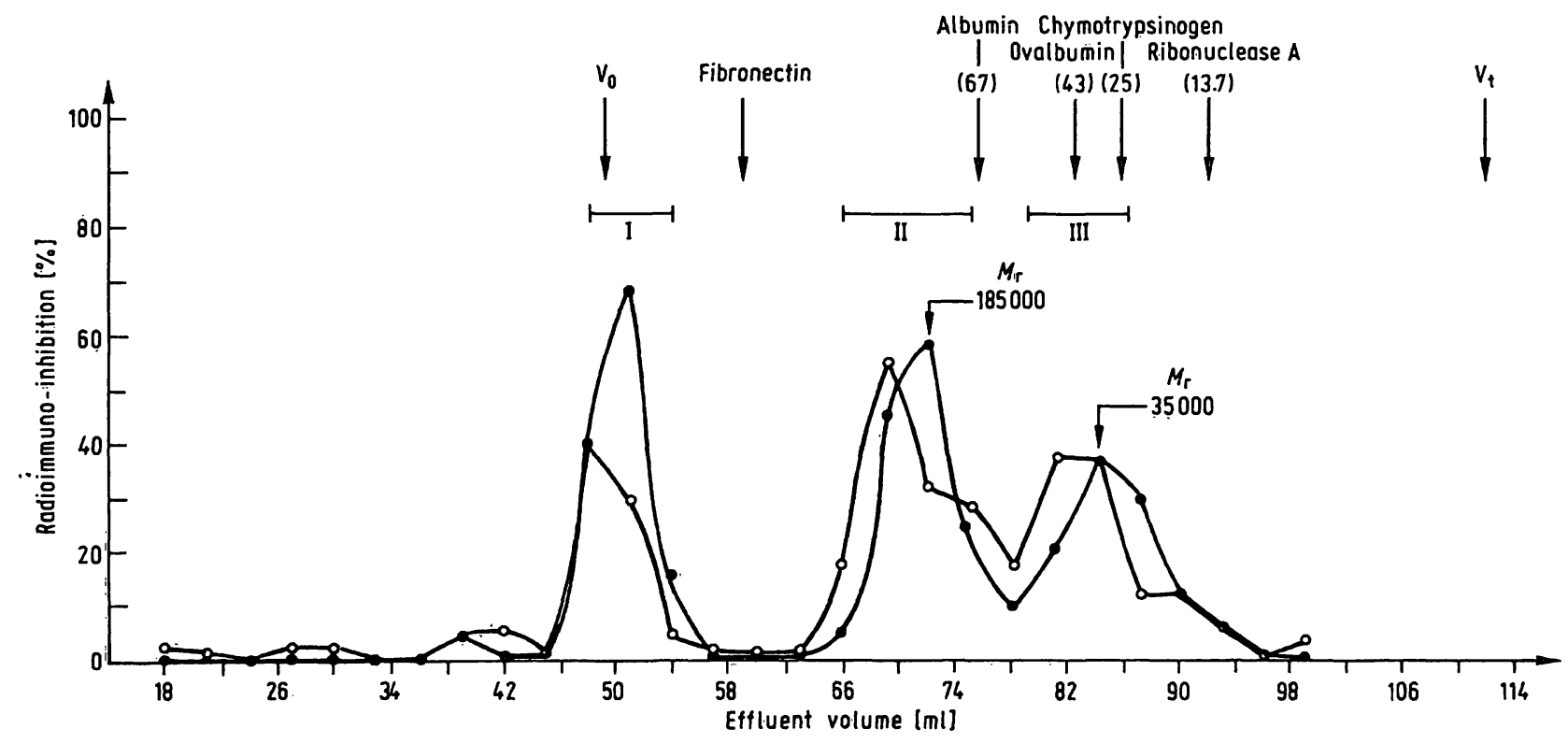

Fig. 5. Elution profiles from a Sephacryl S 300 column of cerebrospinal fluid immunreactive procollagen peptides in the presence $(\mathrm{O}-\mathrm{O})$ and absence $\left(-\mathrm{O}^{-}\right)$of added fibronectin. The column was equilibrated with $0.1 \mathrm{~mol} / \mathrm{l} \mathrm{Tris}-\mathrm{HCl}, \mathrm{pH} 7.4$ and calibrated with various molecular weight standard proteins of which the $k$ daltons are given in parentheses. Cerebrospinal fluid of 3 patients was pooled. One portion of $0.9 \mathrm{ml}(28.5 \mathrm{ng}$ procollagen peptide) was subjected to gel chromatography directly, another portion was incubated with $10 \mu \mathrm{g}$ fibronectin for $1 \mathrm{~h}$ at $37^{\circ} \mathrm{C}$ prior to gel chromatography. The elution profiles of immunoreactive procollagen peptides were recorded, the molecular weights of the peak fractions were calculated from $\mathrm{K}_{\mathrm{av}}$. 


\section{Discussion}

The results presented in this study demonstrate, in human cerebrospinal fluid, the presence of antigenic material that reacts with antibodies produced against the aminoterminal propeptide of bovine type III procollagen. Because of the high immunological cross-reactivity between the respective human and bovine propeptides (11) the immunreactive material identified in cerebrospinal fluid most likely represents procollagen type III fragments. As previously recognized (11) and described in more detail recently (24), the composition of the antigenic material in serum is heterogenous with respect to its molecular weight. The heterogeneity of the procollagen peptides in cerebrospinal fluid described here resembles that in the serum of a patient with chronic active hepatitis, showing at least four peaks. The molecular weight of the bulk fraction was found to be $>$ 100000 which is in line with recent observations (24) demonstrating high molecular weight antigenic material in serum, but different from the original report (11) in identifying mainly a 45000 and 10000 dalton fraction of procollagen peptides in serum. A substantial portion of procollagen peptides in cerebrospinal fluid actually eluted with the void volume of Sephacryl S 300 .

The heterogeneity of the procollagen type III specific material in human body fluids is important in relation to the problem of its radioimmunologic determination, and for the understanding of the metabolic fate of the circulating form of procollagen type III fragments (24). Since the molecular weight of the aminoterminal propeptide was reported to be 45000 dalton $(11,13)$, the high molecular weight fraction must represent either an aggregated form of the propeptide (11) or a more complete fragment of the procollagen molecule containing the aminoterminal determinants. The former assumption seems to be unlikely. It is therefore assumed that at least the high molecular weight fraction does not derive from cleavage of procollagen by the action of procollagen peptidase during procollagen processing, but rather from limited degradation of either newly synthesized procollagen type III or of a procollagen species deposited in the matrix (24).

In the collagen molecule several binding sites for fibronectin have been identified (18). Fibronectin, a high molecular weight glycoprotein also termed cold insoluble globulin (21), binds with high affinity to collagens, preferentially to type III collagen, and this binding is enhanced by heparin $(18-21)$. Since fibronectin is present in high concentrations in blood the heterogeneity of propeptides in serum could be due to various degrees of molecular interactions. In cerebrospinal fluid fibronectin is either absent or present in low concentrations $(22,23)$ which offers the possibility of testing the binding of added glycoprotein to the propeptide under almost physiologic ionic conditions. The results reported above do not indicate such an interaction or the presence of free binding sites on procollagen peptides. The data, however, do not rule out the possibility that all available binding sites are occupied even by the low amounts of fibronectin present in cerebrospinal fluid. Neither the cells responsible for synthesis nor the catabolic sites of the soluble procollagen peptides in the cerebrospinal fluid compartment are known. Thus, the mechanisms controlling the level of procollagen peptide in the fluid and affecting its concentration under certain pathologic conditions are presently not understood. The high concentration of the peptide in cerebrospinal fluids of all infants studied might reflect accelerated collagen synthetic activity and/or turnover during development as observed in serum (25). From the data presented it seems highly unlikely that serum procollagen peptides contribute to the level of the respective peptides in cerebrospinal fluid. The maximum concentration observed $(265 \mu \mathrm{g} / \mathrm{l})$ greatly exceeds that measured so far in serum (13). This suggests that the determination of cerebrospinal fluid procollagen type III peptides might provide a potentially useful parameter of local connective tissue formation and/ or turnover. With respect to the clinical significance of the peptide in cerebrospinal fluid it is of interest that the highest concentrations were observed in patients with art. basilaris aneurysm and haemangioblastoma, respectively. Both diseases might be associated with altered collagen metabolism. Further studies are required for a clinical evaluation of the procollagen type III peptides in cerebrospinal fluid.

\section{Acknowledgment}

The expert technical assistance of Bert Delvoux is greatfully acknowledged. 


\section{References}

1. Thibodeau, S. N., Lee, D. C. \& Palmiter, R. D. (1978) J. Biol. Chem. 253, 3771-3774.

2. Habener, J. F., Rosenblatt, M., Kemper, B., Kronenberg, $H$. M., Rich, A. \& Potts, J. T. (1978) Proc. Natl. Acad. Sci. USA 75, 2616-2620.

3. Campbell, P. N. \& Blobel, G. (1976) FEBS Lett. 72, $215-226$

4. Palmiter, R. D., Davidson, J. M., Gagon, J., Rowe, D. W. \& Bornstein, P. (1979) J. Biol. Chem. 254, 1433-1436.

5. Blobel, G. \& Dobberstein, B. (1975) J. Cell. Biol. 67, $835-851$

6. Prockop, D. J., Kivirikko, K. I., Tuderman, L. \& Guzman, N. A. (1979) N. Engl. J. Med. 301, 13-23.

7. Prockop, D. J., Kivirikko, K. I., Tuderman, L. \& Guzman, N. A. (1979) N. Engl. J. Med. 301, 77-85.

8. Taubman, M. B., Goldberg, B. \& Sherr, C. J. (1974) Science $186,1115-1117$.

9. Taubman, M. B., Kammerman, S. \& Goldberg, B. (1976) Proc. Soc. Exp. Biol. Med. 152, 284-287.

10. Rohde, H., Nowack, H., Becker, U. \& Timpl, R. (1976) J. Immunol. Meth. 11, 135-145.

11. Rohde, H., Vargas, L., Hahn, E., Kalbfleisch, H., Bruguera, M. \& Timpl, R. (1979) Eur. J. Clin. Invest. 9, 451-459.

12. Hahn, E. G. \& Martini, G. A. (1980) Internist 2I, 195-201.
13. Hahn, E. G. (1981) Dtsch. Med. Wochenschr. 106, 950-952.

14. Taubman, M. \& Goldberg, B. (1978) in Collagen Metabolism in the Liver (Popper, H. \& Piez, K. A., eds.) Am. J. Digest. Dis. 23, 641-659.

15. Weichselbaum, T. E. (1946) Am. J. Clin. Pathol. 16, 40-48.

16. Tietz, N. W. (ed.) (1982) Fundamentals of Clinical Chemistry. W. B. Saunders, Philadelphia.

17. Sachs, L. (1972) Statistische Auswertungsmethoden, 3. Auflage, Springer-Verlag, Berlin.

18. Balian, G., Click, E. M., Crouch, E., Davidson, J. M. \& Bornstein, P. (1979) J. Biol. Chem. 254, 1429-1432.

19. Engvall, E. \& Ruoslahti, E. (1977) Int. J. Cancer 20, 1-5.

20. Ruoslahti, E., Vuento, M. \& Engvall, E. (1978) Biochim. Biophys. Acta 534, 210-218.

21. Hörmann, H. (1982) Klin. Wochenschr. 60, 1265-1277.

22. Gressner, A. M. \& Wallraff, P. (1980) J. Clin. Chem. Clin. Biochem. 18, 797-805.

23. Gressner, A. M. \& Wallraff, P. (1981) Clin. Chim. Acta 113, 207-212.

24. Niemelä, O., Risteli, L., Sotaniemi, E. A. \& Risteli, J. (1982) Clin. Chim. Acta 124, 39-44.

25. Probst-Meedt, E., Abiodun, Ph. \& Wolf, H. (1982) Abstr. Falk Symp. 35, 173.

Prof. Dr. A. M. Gressner Abt. für Klinische Chemie und Zentrallaboratorium der Philipps-Universität Uferstraße 2a D-3550 Marburg 
